\title{
Analysis of Web Components in Website Design
}

\author{
C. Purushotham ${ }^{1}, \mathrm{G}$. Sreedhar ${ }^{2}$ \\ ${ }^{1}$ Research Scholar, National Sanskrit University, Tirupati, Andhra Pradesh, India \\ ${ }^{2}$ Research Guide, Professor, National Sanskrit University, Tirupati, Andhra Pradesh, India
}

\section{Article Info}

Volume 7, Issue 1

Page Number: 138-141

Publication Issue :

January-February-2021

\section{Article History}

Accepted : 01 Jan 2021

Published : 04 Jan 2021

\section{ABSTRACT}

The main objective of research article is to measure the download performance of website. In the methodology various elements are taken into consideration viz., HTML tags, Objects, Images, CSS, Scripting, Website size. The download time of website is measured in ranking grades viz. A, B, C, D, E, F etc. The website developer needs to observe the performance of various elements and optimum download time into order to improve the performance of website design.

Keywords : Downloading Time, Front-End Analysis, CSS, Html, Objects, Script, Website Size.

\section{INTRODUCTION}

Today web is not only information resource but also becoming an automated tool in various applications. A website is a collection of related network web resources, such as web pages, multimedia content which are typically identified with a common domain name and hosted through web server. It is the combination of both frontend and back-end. Front-end web development basically deals with web site design. The various technologies required for front-end development are html, css, javascript, etc., Back-end web development mainly deals with web server. The website technologies for web server provide the tasks about web content organisation, storage, download time and hosting the website.

\section{RELATED WORK}

Initially, the web was considered as a collection of static html documents tied together with hyperlinks. However in present situation, there is a need to develop interactive websites for various web users. This may increase the size of website and performance of website is crucial in accessing the website. In order to improve the performance of website various elements of website design need to be taken into consideration. These include website download time, HTML tags usage, CSS, scripting, images, graphics etc., [1].

Javascript's instant popularity happened during the period of the Browser wars. Javascript is a client side dynamic programming language. It is the html and web programming language. Javascript performance really suggests with getting the code onto a page in the most efficient way possible. A large source of performance of 
problems in Javascript is partly written code that uses inefficient algorithms or utilities. In effect, javascript forces the developer to perform the optimizations that a compiler would normally handle in other language [2]. In order to design a website various technologies [3] [4] [5] provide custom elements for website operation. World Wide Web consortium (W3C) defines a set of guidelines for quality of web design. These works stress on the navigational relationship among web pages [6]. Downloading time depends on varies with components such as multimedia, document size, program size and so on [7].

\section{METHODOLOGY}

The methodology for analysing download time of website initially starts with a web program. The program consists of two parts: extracting components of website with download time and download time performance grades. In the web program, all the components of website with corresponding downloading time are extracted using a web tool namely Web Page Analyzer [8] as shown in figure 1 to figure 3 .

\section{Web Page Speed Report}

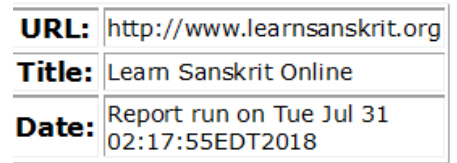

\section{Diagnosis}

\section{Global Statistics}

\begin{tabular}{l|l|}
\hline $\begin{array}{l}\text { Total } \\
\text { HTTP }\end{array}$ & 7 \\
Requests: & \\
\hline Total & $\begin{array}{l}69944 \\
\text { Size: }\end{array}$ \\
\hline
\end{tabular}

Figure 1: Website Analysis

\section{Object Size Totals}

\begin{tabular}{|c|c|c|c|}
\hline $\begin{array}{c}\text { Object } \\
\text { type }\end{array}$ & $\begin{array}{c}\text { Size } \\
\text { (bytes) }\end{array}$ & $\begin{array}{l}\text { Download } \\
\text { @ 56K } \\
\text { (seconds) }\end{array}$ & $\begin{array}{l}\text { Download } \\
\text { @ T1 } \\
\text { (seconds) }\end{array}$ \\
\hline HTML: & 5031 & 1.20 & 0.23 \\
\hline $\begin{array}{l}\text { HTML } \\
\text { Images: }\end{array}$ & 10434 & 2.28 & 0.26 \\
\hline $\begin{array}{l}\text { CSS } \\
\text { Images: }\end{array}$ & 2641 & 0.93 & 0.41 \\
\hline $\begin{array}{l}\text { Total } \\
\text { Images: }\end{array}$ & 13075 & 3.21 & 0.67 \\
\hline Javascript: & 43189 & 9.01 & 0.63 \\
\hline CSS: & 8649 & 1.92 & 0.25 \\
\hline Multimedia: & 0 & 0.00 & 0.00 \\
\hline Other: & 0 & 0.00 & 0.00 \\
\hline
\end{tabular}

Figure 2: Web components size and download time

\section{Analysis and Recommendations}

- TOTAL HTML - Congratulations, the total number of HTML files on this page (including the main HTML file) is 1 which most browsers can multithread. Minimizing HTTP requests is key for web site optimization. $Y$

- TOTAL OBJECTS - Congratulations, the total objects on this page (including the HTML) is 7 which most browsers can multithread in a reasonable amount of time. Minimizing HTTP requests is key to minimizing object overhead (see Figure II-3: Relative distribution of latency components showing that object overhead dominates web page latency in Website Optimization Secrets for more details on how object overhead dominates web page latency.

- TOTAL IMAGES - Congratulations, the total number of images on this page is 3 . Most browsers can send multiple requests, which can speed display of multiple images.

- TOTAL CSS - Congratulations, the total number of external CSS files on this page is 1 . Because external CSS files must be in the HEAD of your HTML document, they must load first before any BODY content displays. Although they are cached, CSS files slow down the initial display of your page. Remember to place CSS files in the HEAD and JavaScript files at the end of the BODY to enable progressive display.

- TOTAL SIZE - Congratulations, the total size of this page is 69944 bytes. This page should load in 15.34 seconds on a 56Kbps modem. Based on current average web page size and composition trends you want your page to load in less than 20 seconds on a 56Kbps connection, with progressive feedback. Ideally you want your page to load in 3 to 4 seconds on a broadband connection, and 8 to 12 seconds for the HTML on a dialup connection. Of course, there's always room for improvement

- TOTAL SCRIPT - Congratulations, the total number of external script files on this page is 2 . External scripts are less reliably cached than CSS files so

Figure 3: Analysis and Recommendations

The website size is dependent on various components of the website. These components include Image Size, Documnets Size, Media Size, Programs or Scripts Size, CSS size and other objects. The relation between website size and web components is shown in equation (1). 
WEBSIZE $=\sum$ (IMG SIZE, DOC SIZE, MEDIA SIZE, CSS SIZE, SCRIPT SIZE, OTHER OBJSIZE)

Where

WEBSIZE $=$ Website Size

IMGSIZE = Images size

DOC SIZE $=$ Documents size

MEDIASIZE $=$ Multimedia size

SCRIPTSIZE $=$ Scripts or programs size

CSSSIZE $=$ Cascading Style Sheetsize

OTHEROBJSIZE = Other objects size like Actice X, AJAX, Jquery etc.

Equation 1 : Relation between website size and web components size

The download time is directly proportional to the page size. The download time performance grade is obtained using the web tool GTMetrix [9] as shown in figure 4 . The GTMetrix web tool analyses the website download time and evaluates the download time performance in $\mathrm{A}, \mathrm{B}, \mathrm{C}, \mathrm{D}, \mathrm{E}$ and $\mathrm{F}$ grades. The page speed grades are provided based on web pages adherence to the rule sets. A good page speed score means web pages are optimized for the browse to render as fast as possible.

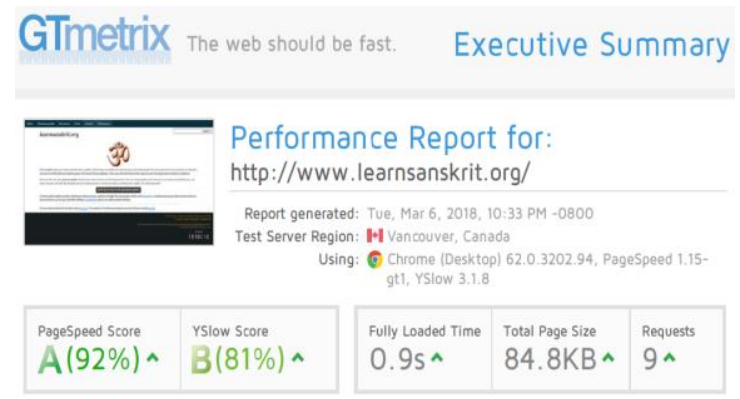

Figure 4: Download time grade of website

Taking consideration of grades obtained, the download time criteria for the websites are provided using the following equation 2 .

$$
\begin{aligned}
& \text { VeryGood } \\
& \text { Good } \quad \text { (if grade }=A \text { ) }
\end{aligned}
$$

$$
\begin{gathered}
\text { Better than avg (if grade }=C) \\
W D T C=\text { Average } \\
\text { Poor } \quad(\text { if grade }=D) \quad \ldots .(2)
\end{gathered}
$$$$
\text { Very Poor } \quad \text { (if grade =F) }
$$

Where

$W C=$ Website Downloading time Criteria Equation 2: website downloading time criteria equation

\begin{tabular}{|c|c|c|c|}
\hline S.NO & WEBSITES & $\begin{array}{l}\text { DOWNLO } \\
\text { AD TIME } \\
\text { PERFORM } \\
\text { ACE } \\
\text { GRADES }\end{array}$ & $\begin{array}{l}\text { WEBSITE } \\
\text { DOWNLO } \\
\text { ADING } \\
\text { TIME } \\
\text { CRITERIA }\end{array}$ \\
\hline 1 & $\begin{array}{l}\text { Sanskrit. } \\
\text { Samskrutam. } \\
\text { Com }\end{array}$ & $\mathrm{D}$ & Average \\
\hline 2 & $\begin{array}{l}\text { www.sanskrt } \\
\text { world.in }\end{array}$ & $\mathrm{C}$ & $\begin{array}{l}\text { Better than } \\
\text { Average }\end{array}$ \\
\hline 3 & $\begin{array}{l}\text { www.sanskrt } \\
\text { academy.com }\end{array}$ & B & Good \\
\hline 4 & $\begin{array}{l}\text { www.learn } \\
\text { Sanskrit.org }\end{array}$ & A & Very good \\
\hline 5 & $\begin{array}{l}\text { https//:the } \\
\text { sanskritlangu } \\
\text { age.com }\end{array}$ & B & Good \\
\hline 6 & $\begin{array}{l}\text { https://sanskr } \\
\text { itsafire.com }\end{array}$ & $E$ & Poor \\
\hline 7 & $\begin{array}{l}\text { https://sanskr } \\
\text { ittutorial.in }\end{array}$ & B & Good \\
\hline 7 & $\begin{array}{l}\text { https://sanskr } \\
\text { ittutorial.in }\end{array}$ & B & Good \\
\hline 8 & $\begin{array}{l}\text { Aupasana. } \\
\text { com }\end{array}$ & A & verygood \\
\hline
\end{tabular}

\section{Implementation}

The methodology is implemented on various Sanskrit related websites and the performance of these websites is tabulated below in table 1 . 


\begin{tabular}{|l|l|l|l|}
\hline S.NO & WEBSITES & $\begin{array}{l}\text { DOWNLO } \\
\text { AD TIME } \\
\text { PERFORM } \\
\text { ACE } \\
\text { GRADES }\end{array}$ & $\begin{array}{l}\text { WEBSITE } \\
\text { DOWNLO } \\
\text { ADING } \\
\text { TIME } \\
\text { CRITERIA }\end{array}$ \\
\hline 9 & $\begin{array}{l}\text { https://www. } \\
\text { Gitasupersite. } \\
\text { Iitk.ac.in }\end{array}$ & C & $\begin{array}{l}\text { Better than } \\
\text { average }\end{array}$ \\
\hline 10 & $\begin{array}{l}\text { http://veda } \\
\text { bhumi.org }\end{array}$ & A & Very good \\
\hline 11 & $\begin{array}{l}\text { http://www. } \\
\text { Pradakshina } \\
\text { m.Com }\end{array}$ & D & average \\
\hline
\end{tabular}

Table 1: Evaluation of the download time performance of websites

The analysis was carried on 11 websites related to Sanskrit. The analysis report are as follows, out of 11, three websites are graded very good, three websites are good, two are better than average, two are average, one is poor. The website designers can optimize their website design and thereby can reduce downloading time by implementing methodology stated.

\section{CONCLUSION}

The main objective of the research article is to analyse the performance of website based on its design. In analysis process various factors are taken into consideration in order to suggest the improvement in website design. A remarkable effort has been made in this paper to identify and investigate all possible parameters for quality web design with improved performance.

\section{REFERENCES}

[1]. Bright, P., 2014.HTML5 specification finalized, squabbling, overspecs continues. From https://arstechnicacom/informationtechnology/2014/10.

[2]. Vamsikrishan Mayalapalli, Srinivas Karri., 2015. Optimizing front-end application of javascript. In: Innovative Research in Science, Engineering and Technology. Vol4, Issue 6, June 2015.

[3]. Yong kong xing, 2019. Research and Analysis of the Front-end framework and libraries in E-Business development. In: ICCAE February 23-25, 2019.

[4]. R.Minto, 2008. The genius belong Google'sbrowser.From:

https://www.ft.com/content.

[5]. R.BenbananFich, 2001. Using protocol analysis to evaluate the usability of a Commercial website. In: Information and Management. Vol39(2001),pp.151-163.

[6]. Techniques for Web Content Accessibility Guidelines by W3C, http://w3c.org.

[7]. G.Sreedhar, 2014. Analyzing download time performance of university websites in India. In: Internation Journal of web science and engineering. Vol.1.No-1(2014).

[8]. Web page anlayzer - Website Optimization (web page speed analysis).

[9]. www.GTmetrix.com

\section{Cite this article as :}

C. Purushotham, G. Sreedhar, "Analysis of Web Components in Website Design", International Journal of Scientific Research in Computer Science, Engineering and Information Technology (IJSRCSEIT), ISSN : 2456-3307, Volume 7 Issue 1, pp. 138-141, January-February 2021. Available at doi : https://doi.org/10.32628/CSEIT206668 Journal URL : http://ijsrcseit.com/CSEIT206668 